\title{
Farmer Share Analysis of Tuna Fishermen in Gorontalo City, Indonesia
}

\author{
Lesman Fa'ana \\ Student of Department Aquatic Resources Management \\ Faculty of Fisheries and Marine Science \\ State University of Gorontalo \\ Lis M Yapanto \\ Department Aquatic Resources Management \\ Faculty of Fisheries and Marine Science \\ State University of Gorontalo \\ Munirah F.Tuli \\ Department Aquatic Resources Management \\ Faculty of Fisheries and Marine Science \\ State University of Gorontalo
}

\begin{abstract}
This research was conducted in Tanjung Kramat Village, Hulonthalangi District, Gorontalo City, Gorontalo Province. This study aims to determine the value of tuna fisherman's farmer share and to determine the marketing channels of tuna in Tanjung Kramat Village. The results showed that the marketing channels for tuna fishers in Tanjung Kramat Village were 2 channels. Channel I is Fishermen-CamarLaut Company-Consumer Countries (Singapore, Malaysia, and Japan) channel II Fishermen - collectors - exporters CV. Baris Tuna Anugerah Gorontalo - Consumer Countries (Singapore, Malaysia, and Japan). The value of farmer share in the channel I gets the value of farmer share which is adjusted to the quality criteria of fish, there is quality A getting farmer share as much as $33 \%$ while on AC quality there is farmer share as much as $41 \%$ and quality $C$ there is farmer share as much as 36\% While in channel II the value of farmer share with fishermen to collectors according to the quality of the fish. In quality A, the farmer share value obtained is $90 \%$, $A C$ quality is $82 \%$ and $C$ quality is $75 \%$, while the farmer share value for collectors is to $C V$. Tuna Anugerah line that is adjusted to the quality of the fish. Quality A gets a farmer share value of $30 \%$ and AC quality gets $26 \%$ and quality $C$ gets a farmer share value of $26 \%$.
\end{abstract}

Keywords: Farmer Share tuna fisherman and marketing channel.

\section{INTRODUCTION}

The development of fisheries in Indonesia is a part of the renewal of economic development that can bring a better life for the fishing community. Fishery resources have an important role, especially in terms of increasing the quality and quantity of fishery products, creating animal protein to meet food and nutritional needs, increasing the level of fishery exports, providing industrial raw materials, providing business opportunities, and providing support for regional development. which prioritizes environmental sustainability and functions. The increase in the marine and fisheries sector begins with the growth of capture fisheries production or aquaculture.

The goal of economic development in the fisheries sector is to be able to carry out business activities 
so that the implementation of fishery activities can be carried out by the Indonesian people themselves, both in terms of production business, marketing business, or management business. It can also provide an operational explanation of the purpose of fishery sector development that wants to achieve targets apart from that it is also able to pay attention, especially in the development of the fisheries sector which leads to sustainable fishery growth and development, namely to increase production output and business productivity. As well as providing opportunities for entrepreneurship and creating good jobs.

Some fishery and marine products, tuna, one of the large pelagic fish species, which is a superior type of fish, can also produce the high potential for export in helping the country's foreign exchange from fish catches of approximately 50-60\%. In conditions like this, it can be shown that fisheries can provide quite good opportunities in increasing the development of fishery exports that prioritize agribusiness. In producing a fishery business from an agribusiness perspective, it is possible to develop and establish companies that are market-oriented and adapted to the potential of marine fishery resources.

The marketing of tuna in Gorontalo is not only to meet the needs of consumers in Gorontalo City but also to be marketed abroad, including Singapore, Malaysia, to Japan in frozen processed form. Tuna marketing will be wider when exporters can cooperate with other parties or institutions that can distribute their goods quickly according to demand. The process of marketing goods will take place efficiently if they can meet the indicators, in this case, namely the existence of justice for the seller in determining the price following a good sales process. In the success of a business, it can be used as a benchmark for business revenue development so that it can achieve a company's own goals. One company that produces tuna fishery products in Gorontalo for export abroad in the form of frozen processing, namely CamarLautcompany which every day can produce more than 2 tons of tuna loin. Based on the explanation above, it is necessary to analyze the Farmer's Share of tuna fishers in Gorontalo City so that the farmer share of tuna fishers and tuna exporters can be known.

This study aims to determine the value of tuna fisherman's farmer share and to find out the marketing channels of tuna in Tanjung Kramat Village.

\section{RESEARCH METHODS}

This research was conducted in Tanjung Kramat Village, Hulonthalangi District, Gorontalo City, Gorontalo Province. This research was carried out for 1 month starting on February 10 to March 10, 2021. The selection of this research location was based on the results of a preliminary survey by paying attention to Tanjung Kramat Village, which is $90 \%$ of the population working as conventional fishermen and also as fishermen catching tuna fish. So that researchers are interested in making Tanjung Kramat Village as a research sample to determine the income of tuna fishermen's Farmer Share to the exporter stage at CamarLaut company. 


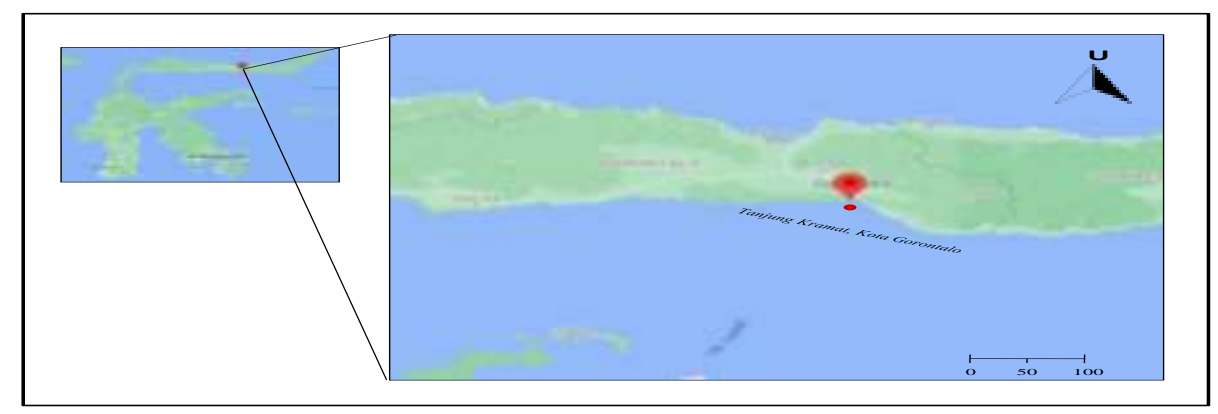

Figure 2. Map of research location

\section{Tools and materials}

The tools and materials and their functions used during this research can be seen in the table below.

Table 3. Tools and Materials and their functions

\begin{tabular}{|c|c|c|}
\hline No. & Tools and materials & Function \\
\hline & Stationary & $\begin{array}{l}\text { Record the information obtained from } \\
\text { the informant }\end{array}$ \\
\hline & Quesionnaire & Interview guide \\
\hline & Cameras and recording devices & Field documentation and interviews \\
\hline
\end{tabular}

\section{Data Types and Sources}

The types and sources of data used in this study are

a. Primary data

Primary data is data that is generated directly from the source. To obtain information, researchers usually use a questionnaire. Primary data is data that is generated directly by researchers from respondents to know the problem under study.

The primary data in this study are data obtained directly from tuna fishermen who enter fish into the CamarLaut company, and factory owner exporter Seagulls company and employees of the company. Seagulls and fishermen who import fish to collectors, and exporters. The employees of Baris Tuna Anugerah using the guided interview method based on the interview guide

\subsection{Farmer Share Nilai}

According to Iswahyudi (2019), farmer share is one indicator to determine the efficiency of marketing operations received by fishermen from marketing activities. To know the efficiency of marketing does not always depend on the high value of farmer share. The marketing margin is based on the function of the marketing channel related to the costs and benefits received by each marketing agency involved. For more details, see the farmer share of tuna fishers in Gorontalo City, see the table 3.

Table 4. Farmer Share of Tuna Fishermen Channel I

\begin{tabular}{|l|l|c|c|}
\hline \multicolumn{4}{|c|}{ Value Farmer Share Channel I Nilai } \\
Fisherman - CV. Sea Gull \\
\hline Fish Quality & Price at Fisherman's & Price in Level & Share (\%) \\
\hline
\end{tabular}




\begin{tabular}{|l|c|c|c|}
\hline & Level (kg) & CV. Seagulls (kg) & \\
\hline A (Export) & $50.000 / \mathrm{kg}$ & $150.000 / \mathrm{kg}$ & \\
AC (local) & $41,000 / \mathrm{kg}$ & $100,000 / \mathrm{kg}$ & \\
C (Local) & $33,000 / \mathrm{kg}$ & $90.000 / \mathrm{kg}$ & \\
\hline
\end{tabular}

Source: personal processed data, 2021

Based on the value of farmer share in channel I fishermen to CamarLaut company that are adjusted to the quality criteria of fish have A quality with a price at the fisherman level of $50,000 / \mathrm{kg}$ while the price is at the company levelof $150,000 / \mathrm{kg}$ which are exported abroad, including Malaysia, Singapore, and Japan, get a farmer share value of 33\%, while for AC quality, the price at the fisherman level is Rp. $41,000 / \mathrm{kg}$, while the selling price is at the CV level. Seagulls of IDR $100,000 / \mathrm{kg}$ which are marketed locally only get a farmer share value of $41 \%$ and quality $\mathrm{C}$ with a selling price at the fisherman level of IDR $33,000 / \mathrm{kg}$ while the price at the exporter level is IDR $90,000 / \mathrm{kg}$ for this quality. also only marketed locally and got a farmer share value of $36 \%$. The highest price value for consumers is found in quality A as much as $150.00 / \mathrm{kg}$ due to the long marketing flow which is exported abroad such as Malaysia, Singapore, and Japan while the lowest price is in the quality of AC fish as much as $90,000 / \mathrm{kg}$. This is only marketed locally, so the marketing is not too long.

Table 5. Farmer Share of Tuna Fishermen Channel II

\begin{tabular}{|c|c|c|c|c|c|}
\hline \multicolumn{6}{|c|}{$\begin{array}{c}\text { Farmer's Value Share Channel II } \\
\text { Fishermen - Collectors - CV. Anugerah Tuna Line }\end{array}$} \\
\hline \multirow[b]{2}{*}{$\begin{array}{l}\text { Fish quality } \\
\text { Fish quality }\end{array}$} & \multirow[b]{2}{*}{$\begin{array}{l}\text { Fisherman's } \\
\text { selling } \\
\text { price } \\
\text { Fisherman's } \\
\text { selling } \\
\text { price }\end{array}$} & \multirow[b]{2}{*}{$\begin{array}{l}\text { Collector's } \\
\text { selling price } \\
\text { Collector's } \\
\text { selling price }\end{array}$} & \multirow{2}{*}{$\begin{array}{l}\text { Selling } \\
\text { price CV. } \\
\text { Anugerah } \\
\text { Tuna Line } \\
\text { Selling } \\
\text { price CV. } \\
\text { Anugerah } \\
\text { Tuna Line }\end{array}$} & \multicolumn{2}{|c|}{ Farmers Share \% } \\
\hline & & & & $\begin{array}{l}\text { Farmers } \\
\text { Share \% }\end{array}$ & $\begin{array}{l}\text { Fish } \\
\text { quality }\end{array}$ \\
\hline A (export) & 50,000 & 55,000 & 180,000 & $90 \%$ & $30 \%$ \\
\hline $\mathrm{AC}$ (export) & 37,000 & 45,000 & 170,000 & $82 \%$ & $26 \%$ \\
\hline $\mathrm{C}$ (export) & 30,000 & 40,000 & 150,000 & $75 \%$ & $26 \%$ \\
\hline
\end{tabular}

Source: processed data, 2021

In channel II, the value of farmer share from fishermen to collectors and CV. Tuna Anugerah line that is adjusted to the quality of the fish. In quality A which is distributed to fishermen to collectors, the selling price of tuna by fishermen to collectors is Rp. 50,000/ $\mathrm{kg}$, and the selling price of collectors to CV. Baris Tuna Award as much as Rp. 55,000/kg while the selling price of tuna is to CV. Baris Tuna Award to consumer countries, namely Japan as much as Rp. 180,000/kg, the value of 
farmer share obtained from fishermen to collectors is $90 \%$ and the value of farmer share to collectors is to CV. The Tuna Award Row is $30 \%$. On AC quality, fishermen sell fish prices to collectors as much as Rp. 37,000/kg and collectors to CV. Baris Tuna Anugerah sells fish prices as much as IDR 45,000/kg while CV. Baris Tuna Anugerah sells fish prices to consumer countries (Malaysia and Singapore) as much as IDR $180.000 / \mathrm{kg}$ the value of farmer share obtained from fishermen to collectors is $82 \%$ and the value of farmer share to collectors to CV. The Tuna Award line is $30 \%$, while in quality $\mathrm{C}$ the selling price of tuna to fishermen to collectors is Rp. 30,000/kg and collectors to CV. Baris Tuna Award as much as Rp. 40,000/kg and the selling price of tuna CV. Baris Tuna Award to consumer countries (Malaysia and Singapore) as much as Rp. 150,000/kg for the value of farmer share to fishermen to collectors to get a farmer share value of $75 \%$ and for the value of farmer share to collectors to CV. Baris Tuna Anugerah got a farmer share value of $26 \%$. This is for Japan only accepts quality $\mathrm{A}$ in tuna to be exported, while Malaysia and Singapore accept all tuna quality for export, namely quality $\mathrm{A}, \mathrm{AC}$, and $\mathrm{C}$. The Tuna Award line is $30 \%$, while in quality $\mathrm{C}$ the selling price of tuna to fishermen to collectors is Rp. 30,000/kg and collectors to CV. Baris Tuna Award as much as Rp. 40,000/kg and the selling price of tuna CV. Baris Tuna Award to consumer countries (Malaysia and Singapore) as much as Rp. 150,000/kg for the value of farmer share to fishermen to collectors to get a farmer share value of $75 \%$ and for the value of farmer share to collectors to CV. Baris Tuna Anugerah got a farmer share value of $26 \%$. This is for Japan only accepts quality A in tuna to be exported, while Malaysia and Singapore accept all tuna quality for export, namely quality $\mathrm{A}, \mathrm{AC}$, and C. The Tuna Award line is $30 \%$, while in quality $\mathrm{C}$ the selling price of tuna to fishermen to collectors is Rp. 30,000/kg and collectors to CV. Baris Tuna Award as much as Rp. 40,000/kg and the selling price of tuna CV. Baris Tuna Award to consumer countries (Malaysia and Singapore) as much as Rp. 150,000/kg for the value of farmer share to fishermen to collectors to get a farmer share value of $75 \%$ and for the value of farmer share to collectors to CV. Baris Tuna Anugerah got a farmer share value of $26 \%$. This is for Japan only accepts quality A in tuna to be exported, while Malaysia and Singapore accept all tuna quality for export, namely quality A, AC, and C. Baris Tuna Award to consumer countries (Malaysia and Singapore) as much as Rp. 150,000/kg for the value of farmer share to fishermen to collectors to get a farmer share value of $75 \%$ and for the value of farmer share to collectors to CV. Baris Tuna Anugerah got a farmer share value of $26 \%$. This is for Japan only accepts quality A in tuna that will be exported, while Malaysia and Singapore accept all tuna quality for export, namely quality A, AC, and C. Baris Tuna Award to consumer countries (Malaysia and Singapore) as much as Rp. 150,000/kg for the value of farmer share to fishermen to collectors to get a farmer share value of $75 \%$ and for farmer share values of collectors to CV. Baris Tuna Anugerah got a farmer share value of $26 \%$. This is for Japan only accepts quality A in tuna to be exported, while Malaysia and Singapore accept all tuna quality for export, namely quality A, AC, and C. Based on Nuriati's research (2018) that farmer share is part of the price received by fishermen who are paid by consumers which can be enjoyed by final producers. In the trading system, it can be said that the more efficient the fisherman receives, the lower the marketing margin. Based on the results of the research that has been stated above, the Farmer Share of each marketing channel, namely, the marketing channel pattern I has a short marketing channel so that the share of the price received by fishermen (farmer share) is quite large, which is $75.00 \%$. marketing channel II has a long channel, the length of the marketing channel causes the share of the price received by fishermen to 
be smaller, which is $57,69 \%$, and the channel III pattern is said to belong because the distance between producers and consumers is very far so that to reach the hands of consumers they have to go through several middlemen. In this study, it was only carried out to middlemen due to limited time, cost and manpower, so that the share of the price received by fishermen was only $65.21 \%$. The high value of farmer share and low value of marketing margin means that the marketing system can be said to be efficient, on the other hand, if the value of farmer share is lower and the value of marketing margin is higher, the marketing system is not efficient. Mufrihah et al (2019). so that the share of the price received by fishermen is only $65.21 \%$. The high value of farmer share and low value of marketing margin means that the marketing system can be said to be efficient, on the other hand, if the value of farmer share is lower and the value of marketing margin is higher, the marketing system is not efficient. Mufrihah et al (2019). so that the share of the price received by fishermen is only $65.21 \%$. The high value of farmer share and low value of marketing margin means that the marketing system can be said to be efficient, on the other hand, if the value of farmer share is lower and the value of marketing margin is higher, the marketing system is not efficient. Mufrihah et al (2019).

According to Downey (1992) in Iswahyudi and Sustiyana (2019), it is stated that the value of farmer's share $40 \%$ is efficient while farmer's share $40 \%$ is not efficient. This is in Channel I the value of farmer share that is obtained to fishermen to CV Seagulls for efficient farmer share value is found in AC quality as much as $41 \%$ while inefficient farmer share value is found in quality $\mathrm{A}$ as much as $33 \%$ and Quality $\mathrm{C}$ as much as $36 \%$. While in channel II the efficient farmer share values are found in quality $\mathrm{A}, \mathrm{AC}$ and $\mathrm{C}$ on the channel to fishermen to collectors, getting Farmer share values for quality A $90 \%$, AC quality $82 \%$, and $\mathrm{C}$ quality $75 \%$ while the inefficient farmer share quality is found. on quality $\mathrm{A}, \mathrm{AC}$, and $\mathrm{C}$ on the channel to the collector and to the $\mathrm{CV}$. Baris Tuna Anugerah gets farmer share value for quality A $30 \%$,

\section{CONCLUSION}

Based on the results of research on farmer share of tuna fishers in Tanjung Kramat Village, Gorontalo City, it can be concluded that the value of farmer share in the channel I get a farmer share value that is adjusted to the quality criteria of fish, there is quality A getting farmer share as much as $33 \%$ while in AC quality there is farmer share. as much as $41 \%$ and quality $\mathrm{C}$ there is a farmer's share of $36 \%$. This is in Channel I for efficient farmer share values found in AC quality as much as $41 \%$ while inefficient farmer share values found in A quality as much as $33 \%$ and $\mathrm{C}$ quality as much as $36 \%$. While in channel II the value of farmer share to fishermen to collectors is adjusted to the quality of the fish. In quality A, the farmer share value obtained is $90 \%$, AC quality is $82 \%$ and $\mathrm{C}$ quality is $75 \%$, while the farmer share value for collectors. Tuna Anugerah line company is adjusted to the quality of the fish. Quality A gets a farmer share value of $30 \%$ and AC quality gets $26 \%$ and quality $\mathrm{C}$ gets a farmer share value of $26 \%$. In channel II the efficient farmer share values are found in quality $\mathrm{A}, \mathrm{AC}$, and $\mathrm{C}$ on the channel to fishermen to collectors, getting Farmer share values for $90 \%$ A quality, $\mathrm{AC}$ quality $82 \%$, and $\mathrm{C}$ quality $75 \%$ while the inefficient farmer share quality is found in quality $\mathrm{A}, \mathrm{AC}$, and $\mathrm{C}$ on the channel to the collector and the Baris Tuna Anugerah obtained farmer share values for $30 \%$ A quality, 26\% AC quality, and $26 \%$ C quality. 


\subsection{Suggestions}

Suggestions that can be submitted based on the results of the study are:

1. For CamarLaut company need a marketing analysis to see the marketing situation of the company/factory and the feasibility of the business being managed

2. The government is expected to support small or large businesses to improve the regional economy and the quality of regional fisheries.

\section{REFERENCES}

1. Aprilia, P., Pontoh, O., Aling, D., RR. (2013). Journal. Marketing of Tuna (Thunnus albacores) Case Study in Bersehati Market, Calaca Village, Manado City.

2. Apsari, W. (2011). Analysis of Indonesian Fresh Tuna Export Demand in International Markets. (dissertation). Graduate School. Bogor Agricultural Institute. Bogor.

3. Hapsari, DT (2013). Distribution and Marketing Margin of Tuna Catches (Euthynnus Affinis) at Tpi Ujungbatu Jepara. Journal of Fisheries Science and Fishery Resources.

4. Iswahyudi and Sustiyana. (2019). Marketing Channel Pattern of Jambu Air the Farmer Share Camplong company. Journal Faculty of Agriculture, Madura Islamic University, Pamekasan.

5. Sustainable. W., Syarif. R., Komar. S. (2013). Strategy to Increase the Competitiveness of Indonesian Processed Tuna in International Markets. Journal. Department of Food Science and Technology, Faculty of Agricultural Technology, Bogor Agricultural University.

6. Luisan, T., Wullur, S., Pondang, M., (2020). Export Procedure Efficiency in Canned Fish Processing Industry in Bitung City. Journal of the Faculty of Economics and Business, Department of Management, Sam Ratulangi University.

7. Mufrihah, L., Iman, T., Faik, K. (2019). Marketing System and Efficiency of Tuna (Euthynnus Affinis) in Cilacap Regency, Central Java. Journal. Fisheries Resource Utilization Study Program, Department of Fisheries, Faculty of Fisheries and Marine Sciences, Diponegoro University.

8. Muslim, C., Valeriana, D. (2012). National Soybean Performance and Farmer Share Analysis and Efficiency of Soybean Marketing Channels in Cianjur Regency. Journal. Researcher at the Center for Socio-Economic and Agricultural Policy.

9. Nuriati Ni Kadek, (2018). Efficiency Analysis of Marketing Channels of Tuna Catches by Fishermen in Seraya Timur Village, Karangsem District. Journal. Department of Economics Education, Faculty of Economics, Ganesha University of Education Singaraja, Indonesia.

10. Nuriati, NK (2018). Efficiency Analysis of Marketing Channels of Tuna Catches by Fishermen in East Seraya Village, Karangasem District. Journal. Department of Economics Education, Faculty of Economics, Ganesha University of Education Singaraja, Indonesia.

11. Olii, AH, Yapanto, LM, \& Akili, SA (2019). The Efficient Handline Fishing Gear In Gorontalo Regency, Indonesia. Asia Journal of Fisheries and Aquatic Research, 10.https://doi.org/10.9734/ajfar/2019/v4i430061 
12. Putra, A (2020). Effect of Marketing Margin Value on Oyster Shell Fishermen's Income in Kuala Village, West Langsa District, Langsa City. (Thesis). Faculty of Agriculture, University of Muhammadiyah North Sumatra, Medan.

13. Rahardi. (2003). Agibicompany Fruit Plants. Self-Help Spreader. Jakarta

14. Rahim, A., Iksan, G., Defidel, W. (2015). Identification of Marketing Channel Distribution of Tempe Chips in Pasir Agung Village, Bangun Purba District, Rokan Hulu Regency (Case Study of Mrs. Pur's Crispy Business). Journal.Faculty of Agriculture, Pasir Pengaraian University.

15. Riswanto, S. (2012). Fishery Status of Bigeye Tuna (Thunnus Obesus) in Indian Ocean Waters. South of the Queen's Harbor. Sukabumi (Thesis) University of Indonesia. Depok.

16. Saanin., H. (1984). Taxonomy and Key Identification of Fish. Build Creation. Bandung.

17. Sudana, IW (2019). Marketing Efficiency Analysis of Fresh Anchovy Catches by Fishermen in Sanggalangit Village, Buleleng Regency. Journal.Department of Marine Affairs and Fisheries of Bali Province.

18. Sudiyono. (2002). Agricultural Marketing. UMM Press Malang.

19. Surwanto, C., Eko, WS, Tri, WN, John, H. (2012). Study of Marketing System of Fish Catches by Fishermen in Gunungkidul Regency, DIY Province. Journal. Students of the Postgraduate Program of IPB, PS Capture Fisheries Capital System (SPT), Department of Fisheries Resources Utilization of IPB.

20. Tanggahu, MS (2019). Export Marketing Analysis of Yellowfin Tuna (Thunnus Albacores) in Gorontalo City (Thesis). Gorontalo State University Faculty of Fisheries and Marine Sciences Department of Water Resources.

21. Omar. (2012). Marketing Mix Strategy In Increasing Sales Volume Of Processed Tuna At PT. Bethel Citra Seyan Gorontalo. Journal of the Faculty of Social Sciences, State University of Gorontalo.

22. Yapanto, LM, Salam, A., \& Hamzah, ZY (2020). Marketing of Tuna Fish in Gorontalo City (The Marketing of Tuna Fish in Gorontalo City) To find out the efficiency of fish marketing with the survey method, according to Singaribuan, use the purposive method. 2(2), 38-45. 